\title{
ECOLOGICAL GENETICS OF A POPULATION OF THE SNAIL CEPAEA NEMORALIS AT THE NORTHERN LIMIT OF ITS RANGE
}

\author{
J. S. JONES \\ Department of Zoology, University of Edinburgh*
}

Received 28.ix.72

\begin{abstract}
SUMmary
The importance of environmental selection in controlling the distribution of genes in natural populations of the polymorphic snail Cepaea nemoralis is a matter of controversy. Populations of this species have been sampled at the northern limit of their range in Scotland.

There were local differences in gene frequency ("area effects ") for shell colour and banding in the study area, none of which could be related to an environmental variable. No dark brown shells were collected.

The frequency of yellow shells was lower than in central populations of this species, and much lower than in southern peripheral populations in Yugoslavia. There are no such regular clines throughout $C$. nemoralis' range in the frequencies of the genes controlling the number of bands on the shell.

The low frequency of yellow shells in northern peripheral populations is likely to be due to the relatively decreased absorption of solar energy by the more light-coloured yellow shells. The absence of a clinal response to gross climatic differences at the loci controlling shell banding might be due to the frequency of these genes in natural populations being determined primarily by coadaptation.
\end{abstract}

\section{INTRODUCTION}

THE polymorphic land snail Cepaea nemoralis (L.) has been extensively used for research into the ecology and genetics of natural populations, as it combines a striking shell polymorphism with the advantages of low mobility and a wide range of ecological preferences. A great deal of information is now available on the genetics of the polymorphism and on the distribution of morph frequencies in natural populations. The shell may be yellow, pink or brown, and may bear up to five dark bands, whose expression may be modified in various ways. Two main patterns of distribution of the genes controlling this polymorphism have been described. In many lowland areas there is an association between morph frequency and the background upon which the snails are living. This is due to differential selection by predators acting against the less cryptic morphs. On chalk downlands and in other exposed habitats, however, a different type of morph frequency distribution is often found. Large ecologically diverse areas are characterised by a limited range of colour and banding morph frequencies, while populations of adjacent and apparently similar areas have quite different frequencies of these morphs. Local differentiations of morph frequency may be maintained in the face of selective predation. The mode of origin and

- Present address: Department of Biology, Royal Free Hospital School of Medicine, University of London, 8 Hunter Street, London WCIN 1BP, England. 
maintenance of these " area effects" is a matter of some controversy. Cain and Currey (1963a) suggest that the distribution of genes in area effects is controlled primarily by environmental selection. On the Marlborough Downs in the South of England, where this pattern of gene distribution was first described, dark brown shells (which appear to be commoner in the northern part of $C$. nemoralis' range) are, they claim, most common in frost hollows. This may also be true for the darker-coloured brown and pink shells on other downlands and on some sand dunes (Cain, 1968; Carter, 1968). Cain (1968) suggests that climatic selection is likely to be important in the control of gene distribution in area effects for both colour and banding in other regions, although it has not always been possible to identify the climatic factors involved.

The difficulty of identifying environmental selective forces even in regions which have much topographical (and therefore presumably microclimatic) variation has led several authors to suggest that environmental selection is not of primary importance in the maintenance of these patterns of gene distribution. A number of mechanisms whereby area effects could evolve and be maintained in a manner which cannot necessarily be related to the action of the environment have been suggested (Goodhart, 1963; Wright, 1965; Clarke, 1968). The importance, if any, of environmental selection in controlling the distribution of genes in area effects remains a matter of controversy.

Populations at the margin of a species' geographical distribution may be expected to show any effects of environmental selection particularly clearly, as they often exist in the face of an ecological stress which prevents the species from extending its range. The frequencies of any genes which do respond to environmental selection may therefore differ from those found in central populations. These selective responses to gross ecological differences might indicate the nature of any micro-environmental selection acting on local populations.

Jones (1973) has described the genetic structure of a southern peripheral population of $C$. nemoralis in Yugoslavia. The frequency of yellow shells is much higher than in the south of England, but the frequencies of the genes controlling the number of bands on the shell do not differ greatly from those found in central populations. This paper is concerned with populations of C. nemoralis at the northern limit of its range in Scotland.

\section{The area studied}

The distribution of Cepaea in Scotland is discussed by Jones and Clarke (1969). Northern peripheral populations were studied on the east coast of Scotland, as snails are more generally distributed than in the west of the country. The main study area lies between Montrose and Stonehaven (fig. 1). Much of this region consists of sandstone. A belt of basic lavas crosses the area, and there are extensive sand dunes north of Montrose. The vegetation of the area correlated with its geology. Most of the hinterland is arable, with few deciduous woods. The basic lavas support a rich and varied flora, particularly on the cliffs north of St Cyrus (Robertson, 1951). South of the river North Esk the main dune plant is marram Ammophila arenaria, but north of the river the dunes form a more complex system of fixed dunes and dune pasture (Gimingham, 1951). 


\section{Methods}

Sampling techniques were similar to those described by Cain and Currey (1963a). All snails collected were used in the analysis of morph frequencies, except in the case of colonies containing both $C$. nemoralis and $C$. hortensis when only adults were used, as these species cannot easily be distinguished when young. The frequency of band fusions was also computed using adults only, because of variable expression of the genes controlling this phenotype in young snails.

\section{Distribution of snails}

Cepaea was rarely found on the sandstone, but occurred in suitable habitats on the lava belt. It was most common on the sand dunes. The majority of non-dune samples were collected from habitats approximating to Cain and Sheppard's (1954) "rough herbage", such as patches of nettles Urtica dioica, umbels Torilis japonica, willowherb Epilobium angustifolium, brambles Rubus spp. and various grasses and composites. Two samples were collected from short grass. C. nemoralis was not found in woods, although $C$. hortensis occurs occasionally in this habitat. Except on the dunes south of the North Esk, the two species were often found together. C. nemoralis was present in large numbers on the dunes. Samples were collected from the seaward face of the dunes every 100 metres from a point 2 kilometres north of Montrose to the river North Esk. These were supplemented with occasional samples from the landward face of the dune ridge. No $C$. hortensis were found on the dunes south of the North Esk. This species makes its appearance on the more stable dunes north of the river, where it usually occurs in mixed colonies with $C$. nemoralis. Nemoralis therefore appears to retain its ability to exclude hortensis from dune habitats (Oldham, 1928) almost to the northern limit of its range. C. hortensis was abundant on dunes near Aberdeen, 30 kilometres north of nemoralis' northern limit in this area.

\section{Distribution of MORPh fRequencies}

Only samples containing at least five snails were used in the analysis of individual samples. The complete data are rather extensive, involving approximately 9000 snails, and have been published elsewhere (Jones and Clarke, 1972). Morph frequencies are mapped in figs. I and 2. There is clearly considerable geographical variation in the frequencies of the different shell colour and banding morphs.

No brown shells were collected. The frequency of yellow shells is generally low, but this morph is locally common in the southern part of the dunes and in the Bervie valley, in the north of the survey area. Unbanded shells are also rather rare, reaching an appreciable frequency only in the southern and central parts of the dunes and in some samples in the Bervie valley. Midbandeds were found only in the central part of the Montrose dunes. There are several steep clines in the study area-for example, in one locality on the dunes the frequency of unbanded shells rises from 0 per cent. to 93 per cent. in 200 metres.

\section{Discussion}

\section{(i) Association of morph frequency with environment}

The range of habitats in which $C$. nemoralis was found is more limited than that described by Cain and Sheppard (1954) in the south of England, as no 
woodland or hedgerow samples were collected. There are no clear associations between the frequency of yellow or of unbanded shells and the background upon which the snails are living, although rodent predation is locally

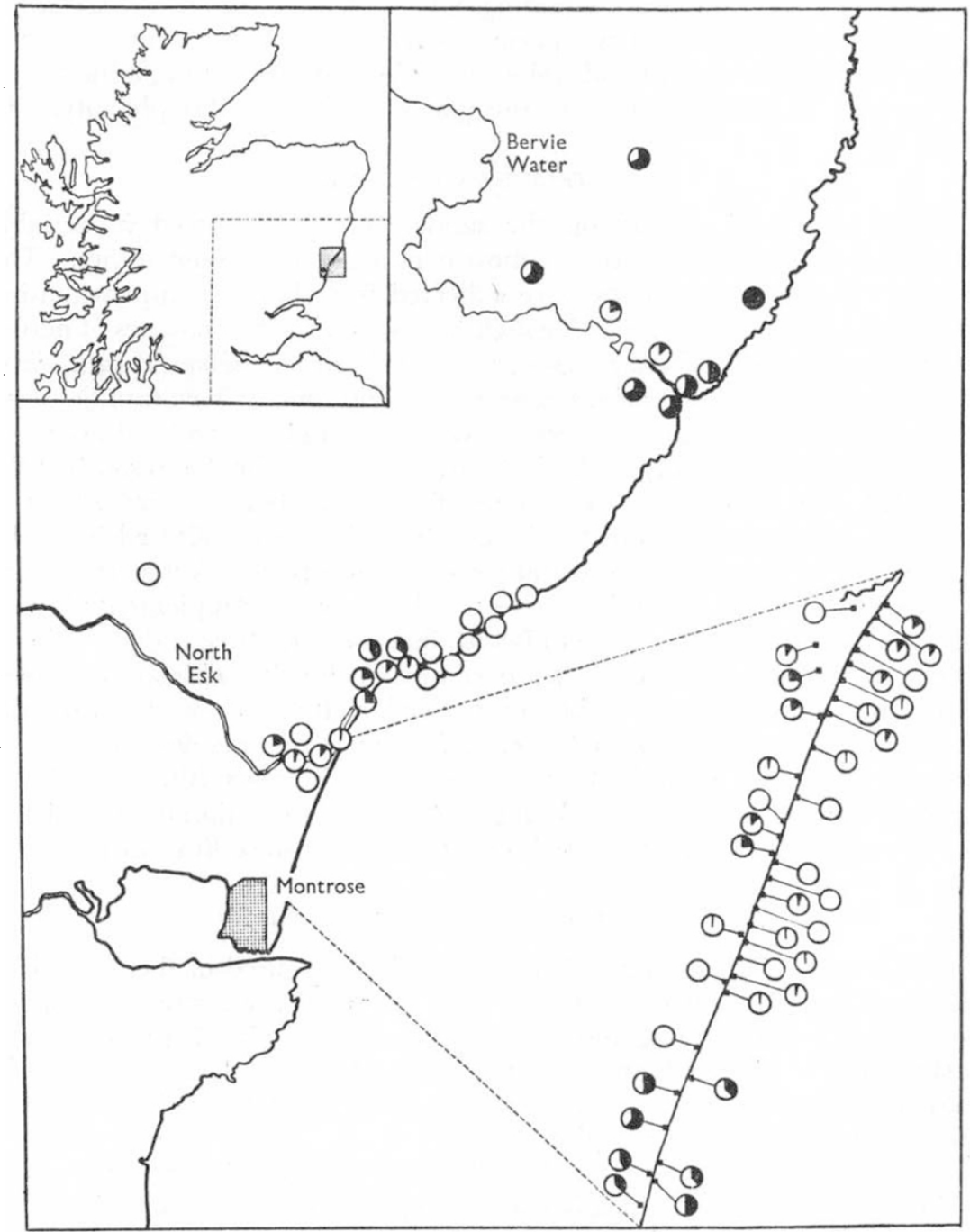

Fro. 1.-Frequency of yellow shells (black sector) in populations of $C$. nemoralis in the Montrose area. Inset shows location of the main study area (stippled) and of the region included in fig. 3 (enclosed by dotted line).

intense. It is apparent that ecologically dissimilar but geographically conjunct areas have similar morph frequencies while ecologically similar but geographically disjunct areas have different morph frequencies. There are therefore area effects for yellow and for unbanded shells in these northern peripheral populations. Midbandeds are found only in one part of the dunes, so that it is not possible to establish that homogeneity of gene frequency in the face of a heterogeneous environment which is, strictly speaking, part of the 
definition of an area effect. It seems likely, however, that the pattern of geographical variation at this locus is similar in kind to that found at the loci controlling shell colour and the presence of bands on the shell.

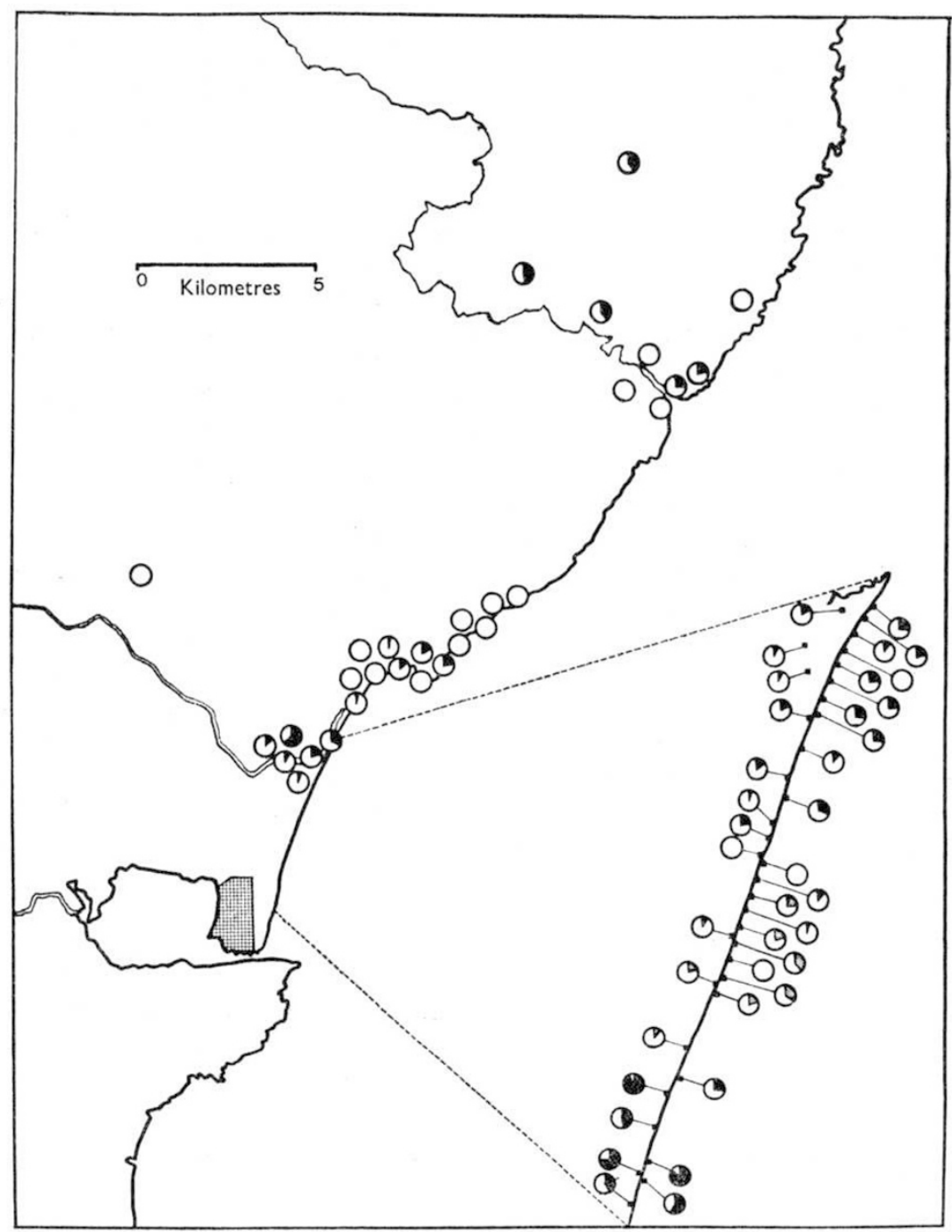

Frc. 2.-Frequency of unbanded (black) and of midbanded (stippled) shells in populations of $C$. nemoralis in the Montrose area.

The distribution of band fusions does show some association with background, as the frequency of shells with bands fused together (computed among adult shells capable of expressing this phenotype) is considerably lower on the dunes than in other habitats (9 per cent. compared to 35 per cent.). This concurs with the observation of Gain (1968) that British and Irish populations usually have a high frequency of emphatically banded shells, which harmonise with the "stripy" background of marram grass. 
The association is consistent with the action of yisual selection. The absence of dark browns from these simple dunes also agrees with the suggestion of Cain (1968) that this phenotype is found primarily on complex dunes which possess enclosed pits in which cold air might accumulate.

There are no clear associations of the frequency of yellow or of unbanded shells with height, aspect or slope of the sampling site. The area effects for these morphs therefore resemble many others which have been described in which morph frequency bears no detectable relationship to environment.

\section{(ii) Comparison with other populations}

Peripheral populations may exist in the face of environmental stress which is preventing extensions of a species' range. The frequencies of any genes which show a response to selection by these environmental factors may be expected to differ from those found in the centre of its distribution. Populations at the northern limit of $C$. nemoralis' distribution may be particularly interesting as they might provide a means of testing Cain and Currey's (1963a) suggestion that the cold conditions found in the north part of this species' range favour dark brown shells, and that this may be reflected in the microgeographical distribution of dark browns.

No dark brown shells were collected in the Montrose area, and this morph is at a low frequency throughout Scotland (Jones and Clarke, 1972). The lack of a high frequency of dark browns in these northern peripheral population of $C$. nemoralis has been interpreted by Clarke (1968) as suggesting that this morph does not have a selective advantage in cold conditions. He suggests that climatic selection may therefore be unimportant in controlling the geographical distribution of dark brown shells in local populations, and that the available evidence does not justify claims that microclimate and environmental selection are generally important in controlling the distribution of genes in area effects. However, Cain (personal communication) has emphasised the complexity of action possible when climate acts as a selective agent. Cain points out that the absence of brown shells in northern peripheral populations in an area which has a low mean summer temperature does not prove that this morph will not be favoured in places which are subject to occasional very low night minimum temperatures, and that a local association with low night minima does not necessarily indicate that the frequency of browns will increase consistently until the northern limit of the species' range is reached. It is not justifiable to argue that lack of a close association with one aspect of a climatic variable means that other aspects of this variable are unimportant, although general trends of association of morph frequency with climate may be useful in evaluating the selective importance of this type of environmental selection. This point is a valid one.

Jones (1973) has shown that southern peripheral populations of $C$. nemoralis in Yugoslavia differ from central populations mainly in that they have a very high frequency of yellow shells (frequency of yellow $=95.0$ per cent. compared to 53.5 per cent. over all British samples).

Snails with yellow shells are comparatively rare in the Montrose area, the overall frequency of yellow being 15.9 per cent. Fig. 3, in which the frequency of this morph is mapped on the basis of the 10-kilometre squares of the British National Grid shows that it is at a low frequency in populations of $C$. nemoralis near the northern limit of its range throughout south-east Scotland. This figure should be compared with fig. 3 of Jones (1973) in 
which the frequency of yellow is mapped on the basis of 10-kilometre squares in Yugoslavia. The existence of a morph-ratio cline at the colour locus from the north to the south of $C$. nemoralis' distribution is clearly demonstrated in the histograms shown in fig. 4. Morph frequencies are compared for samples from south-east Scotland, from National Grid 100-kilometre square SU,

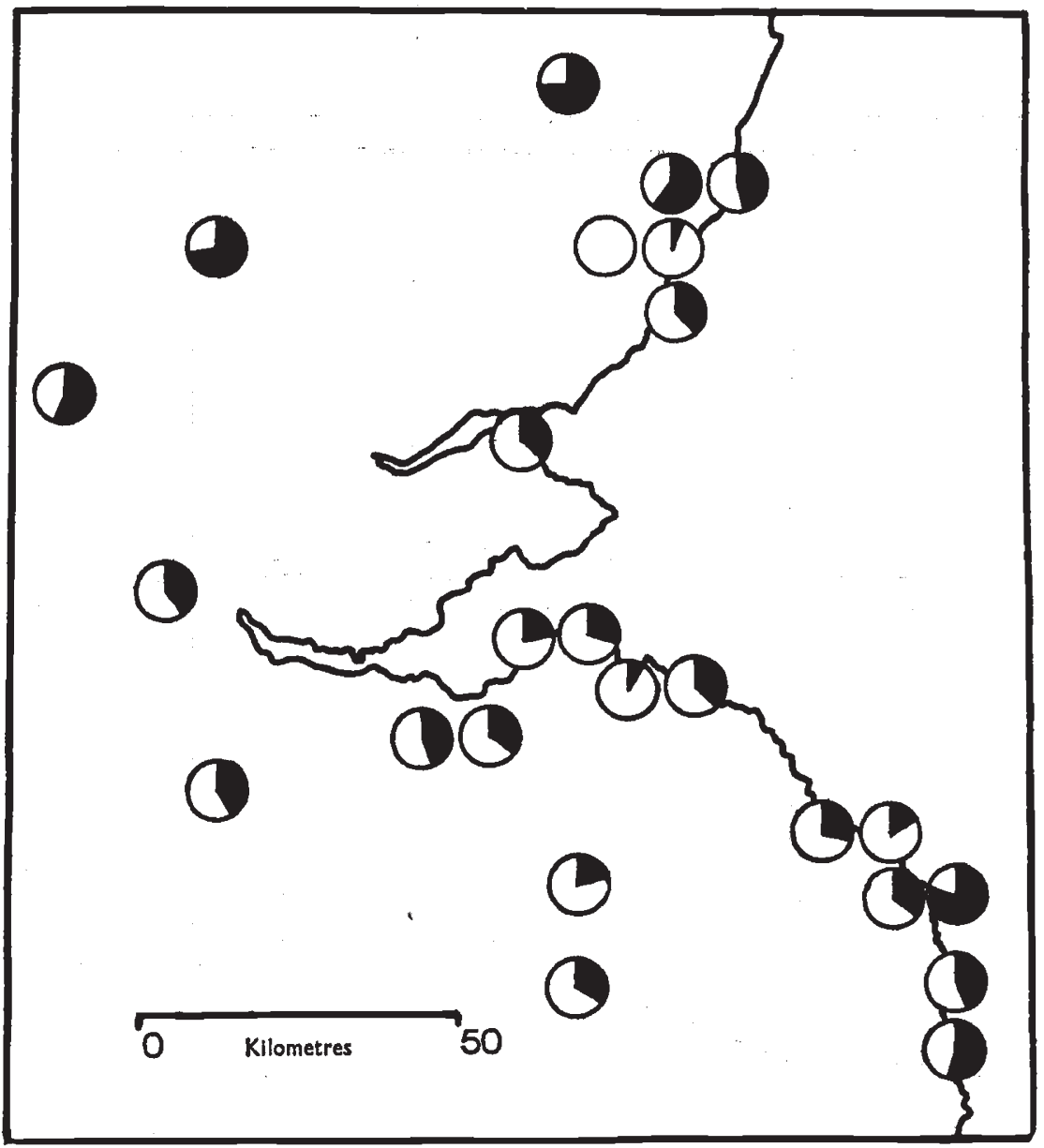

FIG. 3.-Frequency of yellow shells (black) in populations of $C$. nemoralis in south-east Scotland mapped on the basis of 10-kilometre squares of the National Grid.

which includes both the Marlborough Downs (Gain and Currey, 1963a) and the Oxford area (Cain and Sheppard, 1954) as well as other populations studies by Cain and Sheppard, 1952; Sheppard, 1952; Clarke, 1962; Cain and Currey, 1963b; Arnold, 1966; Carter, 1968; Cameron, 1969; Clarke (unpublished) and Diver (unpublished), and from southern peripheral populations in Yugoslavia. The median frequency of yellow shells rises from 25 per cent. to 46 per cent. to 100 per cent. with distance from the northern limit. This is correlated with an increase in mean summer temperature from $13 \cdot 5^{\circ} \mathrm{C}$. to $15 \cdot 5^{\circ} \mathrm{C}$. to $19 \cdot 0^{\circ} \mathrm{C}$. (Anonymous, 1958 ; Booth, 1966). 

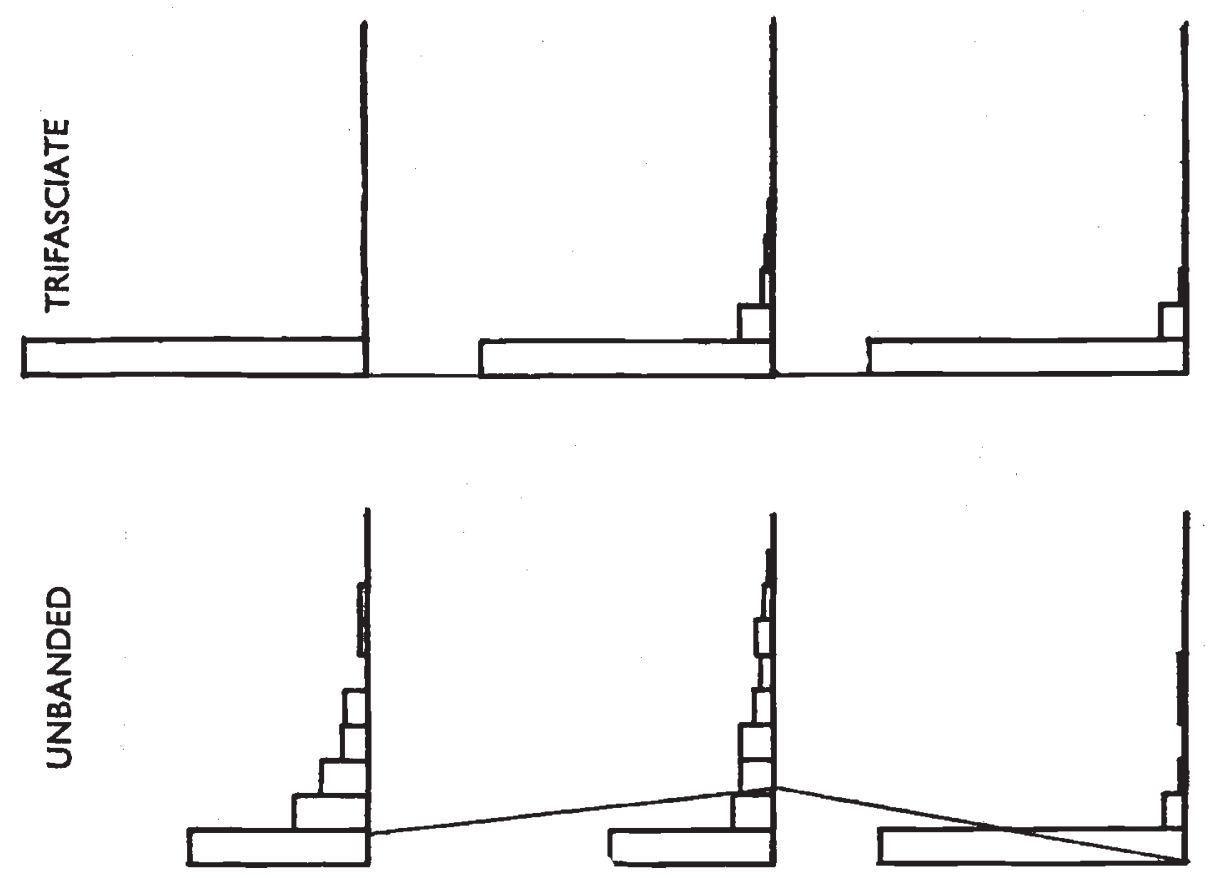

氖

总

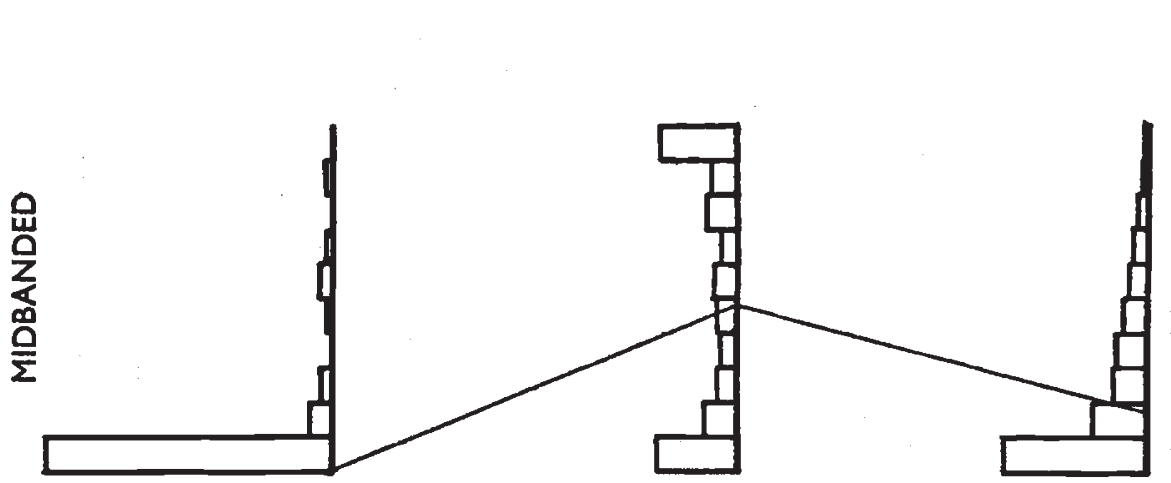

惫

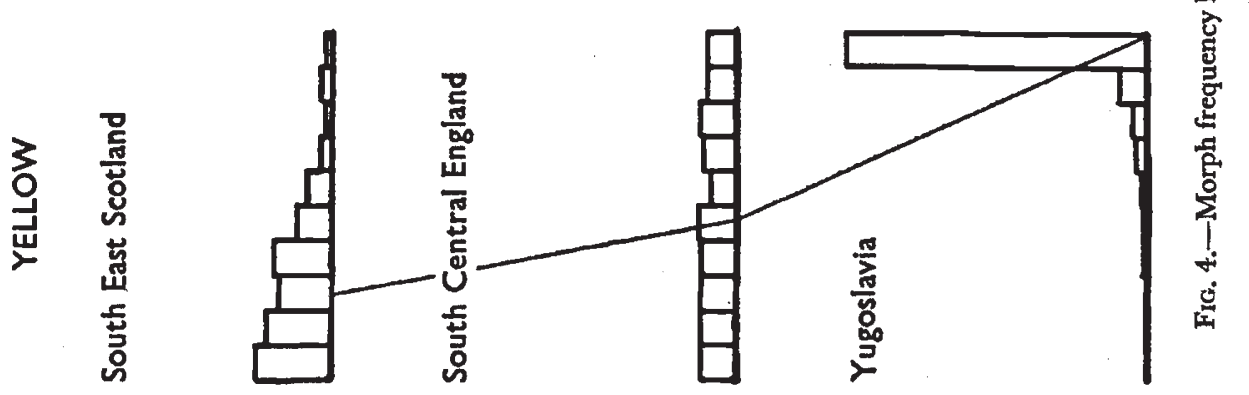


I have argued (Jones, 1973) that the selective advantage of snails with yellow shells in hot places is likely to be due to their relatively light pigmentation and to their associated reduced absorption of solar radiation compared to pinks and browns. Dark-coloured shells will be favoured in northern peripheral populations as they have an increased efficiency of solar absorption. Experiments on insects (Watt, 1968, 1969) and molluscs (Yom-Tov, 1971) have confirmed that dark-coloured animals are at an advantage in conditions where it is necessary to obtain maximum solar energy in order to reach a temperature suitable for metabolic activity, while light-coloured are favoured in conditions where there is an extreme heat load.

Fig. 4 also shows that there are no consistent clines in the frequencies of the major genes controlling the number of bands on the shell throughout the range of $C$. nemoralis. Similarly, Cain and Currey (1963a) were unable to identify an environmental factor influencing banding area effects on the Marlborough Downs, and there is evidence that it is easier to associate the frequencies of the shell colour genes than the shell banding genes with environment in other downland regions (Carter, 1968). It is, however, possible to associate banding morph frequencies with topography in a Pyrenean valley (Arnold, 1968); other valleys in the Pyrenees do not show this pattern of association (Jones, in preparation).

Recent work (Carter, 1968; Arnold, 1970) has also shown that in some places the frequency of shell colour genes responds to the action of selective predation, while that of the banding genes is independent of the background upon which the snails are living, and depends on a systematic or regional effect. It therefore appears to be generally more difficult to establish environmental correlations for banding morph frequency than for colour morph frequency both on the microgeographical and on the large scale. It is possible that this is the result of the genes controlling shell banding having strong selective interactions with other genes, and to the nature of these interactions varying from place to place (Jones, 1972). Such local interactions, the results of which are often diagnosed as "co-adaptation", are known to exist in populations of other animals. The genes controlling the shell colour polymorphism (which occurs in only two of the four species of Cepaea) may not have evolved such interactions, so that their frequencies are more free to respond to selection by ecological factors. Differential responses to environmental selection may therefore help to explain the distribution of genes in $C$. nemoralis both on the local and on the global scale.

An investigation of morph frequency distribution in C. nemoralis throughout Europe in relation to climate using the methods of principal component analysis has been started (Jones, Storey and Williamson, in preparation). This may indicate whether the frequencies of shell banding genes are indeed generally less responsive to climatic selection than are the frequencies of alleles at the colour locus. It may also suggest whether climatic factors other than mean summer temperature are acting which might explain why dark brown shells are rare in northern peripheral populations in spite of some apparent local associations of this morph with a cold microclimate. Although a great deal remains to be understood before a complete explanation of area effects in Cepaea is available, this investigation of peripheral populations of C. nemoralis suggests very strongly that climatic selection plays some part in affecting the distribution of genes in natural populations of this species. 
Acknowledgments. - I am very grateful to the numerous people who assisted in collecting samples, and in particular to Dr and Mrs T. H. Day for their assistance in collecting and in scoring some of the snails. I am also indebted to the Rt. Hon. The Earl of Southesk, K.C.V.O . and to the Southesk Estates Company for the facilities which they provided; to the Nature Conservancy for permission to collect on the St Cyrus National Nature Reserve; and to Professor A. J. Cain and Professor B. C. Clarke for useful discussions. This work was carried out with the assistance of research grants from the Royal Society, the Carnegie Trust for the Universities of Scotland, and the University of Edinburgh.

\section{REFERENCES}

ANonymous. 1958. Klimatski Podaci za Gospić, Razdoblje 1946-1955. Hidrometeoroloski Zavod N. R. Hrvatske, Zagreb.

ARNOLD, R. W. 1966. Factors affecting gene-frequencies in British and continental populations of Cepaea. D.Phil. Thesis, Oxford University.

ARNOLD, R. W. 1968. Studies on Cepaea. VII. Climatic selection in Cepaea nemoralis (L.) in the Pyrenees. Phil. Trans. Roy. Soc. Lond., B, 253, 549-593.

ARNOLD, R. W. 1970. A comparison of populations of the polymorphic land snail Cepaea nemoralis (L.) living in a lowland district in France with those in a similar district in England. Genetics, 64, 589-604.

воотн, R. в. 1966. 1931-60 monthly and annual maps of mean daily maximum and mean daily minimum temperature, and of a verage summer and winter temperature over Great Britain and Northern Ireland. Climatological Memorandum 43. Meteorological Office, London.

CAIN, A. J. 1968. Studies on Cepaea. V. Sand dune populations of Cepaea nemoralis (L.). Phil. Trans. Roy. Soc. Lond., B, 253, 499-517.

cain, A. J., And currey, J. D. 1963a. Area effects in Cepaea. Phil. Trans. Roy. Soc. Lond., $B, 246,1-81$.

CAIN, A. J., AND CURREY, J. D. 1963b. Area effects in Cepaea on the Larkhill Artillery Ranges, Salisbury Plain. F. Linnaean Soc. Lond. (Zool.), 45, 1-15.

CAIN, A. J., AND SHEPPARD, P. M. 1952. The effects of natural selection on body colour in the land snail Cepaea nemoralis. Heredity, 6, 217-231.

CAIN, A. J., AND SHEPPARD, P. M. 1954. Natural selection in Cepaea. Genetics, 39, 89-116.

CAMERON, R. A. D. 1969. The distribution and variation of three species of land snail near Rickmansworth, Hertfordshire. F. Linnaean Soc. Lond. (Zool.), 48, 83-111.

CARTrR, M. A. 1968. Studies on Cepaea. II. Area effects and visual selection in Cepaea nemoralis (L.) and Cepaea hortensis. Phil. Trans. Roy. Soc. Lond., B, 253, 397-446.

CLARKE, B. C. 1962. Natural selection in mixed populations of two polymorphic snails. Heredity, 17, 319-345.

CLARKE, B. C. 1968. Balanced polymorphism and regional differentiation in land snails. In Evolution and Environment, Ed. E. C. Drake: 351-368. Yale University Press, New Haven.

gimingham, c. H. 1951. Contributions to the maritime ecology of St. Cyrus, Kincardineshire. Part II. The sand-dunes. Trans. Bot. Soc. Edinburgh, 35, 387-411.

GOODHART, C. B. 1963. "Area effects" and non-adaptive variation between populations of Cepaea (Mollusca). Heredity, 18, 459-465.

JoNEs, J. s. 1973. The genetic structure of a southern peripheral population of the snail Cepaea nemoralis. Proc. Roy. Soc., Lond., B, 183, 371-384.

Jones, J. s., AND Clarke, B. C. 1969. The distribution of Cepaea in Scotland. F. Conchology, 27, 3-8.

JONES, J. s. 1972. Studies on the ecological genetics of Cepaea. Ph.D. Thesis, University of Edinburgh.

JONEs, J. S., AND CLARKE, B. C. 1972. Populations of the snail Cepaea nemoralis from southeast Scotland. Evolutionary Genetics Res. Rep., 11, 1-7. Filed at the National Lending Library for Science and Technology, Boston Spa, Yorkshire, England.

oldham, c. 1928. Cepaea hortensis and Arianta arbustorum on blown sand. Proc. Malacol. Soc. London, 18, 144-146.

ROBertson, E. T. 1951. Contributions to the maritime ecology of St. Cyrus, Kincardineshire. Part I. The cliffs. Trans. Bot. Soc. Edinburgh, 35, 370-387.

sHEPPARD, P. M. 1952. Natural selection in two colonies of the polymorphic land snail Cepaea nemoralis. Heredity, 6, 233-238. 
WATT, w. B. 1968. Adaptive significance of pigment polymorphism in Colias butterflies. 1. Variation of melanin pigment in relation to thermoregulation. Evolution, 22, 437-458. WATT, w. B. 1969. Adaptive significance of pigment polymorphism in Colias butterflies. II. Thermoregulation and photoperiodically controlled melanin variation in Colias eurytheme. Proc. Natl. Acad. Sci. U.S., 63, 767-774.

WRIGHT, s. 1965. Factor interaction and linkage in evolution. Proc. Roy. Soc. Lond., B, 162, 80-104.

YoM-TOV, Y. 1971. Body temperature and light reflectance in two desert snails. Proc. malacol. Soc. London, 39, 319-326. 